\title{
HR Practices as Antecedents of Supply Relationship Integration: The Inter- and Intra-Firm Contexts
}

\author{
Marie Koulikoff-Souviron ${ }^{1,2}$, Sophie Claye-Puaux ${ }^{3}$ \\ ${ }^{1}$ SKEMA Business School, Nice-Sophia Antipolis, France \\ ${ }^{2}$ CRET-LOG, Aix-en-Provence, France \\ ${ }^{3}$ CRET-LOG, Aix-Marseille Université, Aix-en-Provence, France \\ Email: marie.koulikoff@skema.edu
}

Received July 31, 2013; revised September 1, 2013; accepted September 10, 2013

Copyright (C) 2013 Marie Koulikoff-Souviron, Sophie Claye-Puaux. This is an open access article distributed under the Creative Commons Attribution License, which permits unrestricted use, distribution, and reproduction in any medium, provided the original work is properly cited. In accordance of the Creative Commons Attribution License all Copyrights (C) 2013 are reserved for SCIRP and the owner of the intellectual property Marie Koulikoff-Souviron, Sophie Claye-Puaux. All Copyright (C) 2013 are guarded by law and by SCIRP as a guardian.

\begin{abstract}
This research draws on organizational constructs to investigate the role of HR practices as antecedents of supply relationship integration in inter- and intra-firm contexts. We argue that HR practices can be designed to follow a "specialized" approach or to follow a "relational" approach by promoting collaboration and information sharing at supply relationship level. Drawing on inductive case data from two earlier papers, we identify HRPs supporting standardization as a critical facilitator of inter-firm integration and HRPs supporting mutual adjustment as a critical facilitator of intra-firm integration. This paper contributes to operational integration literature by highlighting the role of HRM in supply relationship integration.
\end{abstract}

Keywords: Supply Relationship; Integration; Organizational Drivers; HR Practices; Case Study

\section{Introduction}

One way to address growing environmental pressures on supply relationships is to intensify efforts for integration, both in inter- and intra-firm contexts [1]. Integration requires that interdependent units adjust to each other and therefore adapt their operations to the partner [2,3]. Interdependence is a key characteristic of organizational integration along with the time span for reciprocity and interaction pattern $[2,4,5]$. Different studies have investtigated the drivers of internal and/or external integration $[4,6,7]$, identifying organizational practices that inhibit or facilitate integration. Though internal and external integrations are distinct processes [1], the specificities of organizational drivers in intra and inter-firm integration contexts have not been empirically addressed [4].

Human aspects are keys to integration because integrated processes require the close collaboration of a large number of people [4]. Coordinative and cooperative behavior can be encouraged through multi-functional teams, careful selection of team members and appropriate reward systems [6,8-10]. A feature of HR practices that promote integration is that they are based on outcomes at relationship rather than individual unit level [7]. As such, HR practices can be designed to follow a "specialized" approach and facilitate coordination within the individual site [11] or to follow a "relational" approach by promoting collaboration and information sharing at supply relationship level [8-11]. HR practices thus can be viewed as antecedents of organizational drivers of integration [10]. This premise is supported by the body of literature that looks at the role of HR practices in inter-firm [12-14], and intra-firm supply relationship contexts [15].

The aim of this study is to contribute to the understanding of integration mechanisms by investigating the similarities and differences among HR practices in the intra- and inter-firm contexts and how they constitute antecedents of organizational drivers - are they inhibitors or facilitators - of supply relationship integration. For that purpose, this study builds on and compares data from two case studies, presented in earlier papers: the first between separately (US-) owned partners in the chemical industry in the UK [14] and the second between French and English sites of a recently merged pharma- 
ceutical firm that worked at different stages in the manufacture of a drug [15]. The paper presents a cross-case analysis and draws conclusions on how HR practices as antecedents of organizational drivers can either inhibit or facilitate integration in the two contexts. Our findings have practical implications for the design of HR practices at two levels: within MNCs characterized by complex and fragmented internal operational environments (intra-firm) and within external strategic supply relationships characterized by reciprocal interdependence (interfirm). The paper contributes to the operational integration literature by highlighting intra and inter-firm specificities of HRM in supply relationships.

The remainder of the paper is structured as follows: first we present the literature on organizational drivers of supply relationship integration; second, we discuss the role of HR practices and introduce our research model and propositions; third we present the methodology; fourth we show the findings and fifth the discussion and conclusion.

\section{Literature Review}

\subsection{Organizational Drivers of Supply Relationship Integration}

Many definitions have been proposed for the concept of integration. In the field of operations management, supply chain integration may be defined as the coordination and collaboration among supply chain partners on intra and inter-organizational processes in order to achieve effective and efficient flows of products, services, information, money and decisions [16]. With a broader, organizational perspective, Barki and Pinsonnault [4] define integration as "the extent to which distinct and interdependent organizational components constitute a unified whole' (p. 166). They distinguish between integration of processes that are internal vs. external, and integration of primary (those that directly produce an organization's output) vs. secondary processes (those that support the primary activities). These distinctions are relevant in the field of OM [7]. This research focuses on integration of primary processes - that is the supply relationship - both at intra- and inter-firm context. For the purpose of our study, intra-firm refers to supply relationships between plants of a single company, which is a common feature of multinational companies; inter-firm refers to strategic supply relationships between plants belonging to distinct companies.

In OM studies, the scope of integration varies signifycantly. From the narrowest to the broadest perspective, studies may refer to: internal (intra-plant) integration, dyadic integration, triadic (chain level) integration and extended (network level) integration [17]. The level of analysis of our study is dyadic, as we focus on integra- tion in intra and inter-firm buyer-supplier relationships.

Within buyer-supplier relationships, factors that inhibit integration can be grouped into two categories: specialization and political barriers [4-6].

Specialization may act as a barrier to integration through two different routes: goal and frame differences. Different goals and priorities have been found to hinder integration [18], in that they promote a local focus and goal orientation [4]. Reward systems aligned on different organizational goals can create conflicts within supply relationships [13]. Different frames of reference can also inhibit integration: as partners lack a common organizational or work background, they do not develop the cognitive models and tacit knowledge that enable communication and coordination [6]. Lack of understanding of the partner is the result of limited direct, face to face communication and socialization [7-9].

Another potential barrier to integration is power and political considerations [4-6]. Transactional relationships are characterized by temporary, impersonal ties, which focus on calculation of benefits and costs and manipulation [19]. The political aspects of power struggles in terms of competition for scarce resources are more important in intra- than inter-firm contexts [4].

Four main mechanisms can facilitate integration [4,6-20]: shared values [6] that is establishing common norms and beliefs through various mechanisms for face to face communication [7], socialization [9] and joint problem solving [5]; direct supervision involving someone responsible for coordinating the activities; standardization of work or knowledge and mutual adjustment, which allows individuals or teams to adapt to each other as the work progresses [2-4].

Harzing [21] classified the control mechanisms in MNCs based on two dimensions. The direct/indirect dimension relates to the explicit or implicit nature of control over subsidiaries. The personal/impersonal dimension, also labeled cultural/bureaucratic or cultural/technocratic, indicates that control may be realized through social interactions or through instrumental artefacts. At the junction of these dimensions, four types of control mechanisms are identified. The direct-personal type denotes the idea of hierarchy and direct supervision. The direct-impersonal type refers to written manuals and standardization. The indirect-personal type concerns socialization and networks, shared values and goals, informal information exchange, and team work. Finally, the indirect-impersonal type refers to "output control". While the three former types focus on controlling behaviors, the latter type of mechanism oversees results.

We draw on Harzing's [21] framework to classify the organizational drivers of integration. Some are explicitly directed toward integration (eg. standardization of work), while others, such as shared values, act toward integra- 
tion in an implicit manner. Additionally, some drivers are founded on social interactions (eg. mutual adjustment), while others draw on instrumental artefacts (eg. resource allocation). Table 1 presents this classification, and specifies the nature of the drivers: facilitators (indicated by a positive sign) or inhibitors (indicated by a negative sign).

According to the above literature, these different drivers should act in the same way in both intra and interfirm contexts of integration, except for political barriers. Indeed, Barki and Pinsonneault [4] suggest a prevalence of political barriers (political considerations and resource allocation problems) in the intra-firm context, as political struggles are typically more important within the confines of an organization. In a context of reciprocal interdependence, the competitive stakes of performance outcomes in external integration tend to cancel out the possible inter-firm political barriers.

\subsection{The Role of HR Practices in Integrating Supply Relationships}

Past research has studied the characteristics and role of human resource management within supply chains. Many studies have adopted an internal plant-level analysis; they have sought to understand and measure the impact of human resource strategies on operations management and performance [22-29]. Pagell [7] identified human drivers of operations, purchasing and logistics integration at site level.

Studies focusing on dyads have been numerous at inter-firm level but quite neglected at intra-firm level. Inter-firm dyad studies highlight the need for HRM involvement in strategic SC partnerships [30-34] in a way to align HR practices with customer requirements [35-36] or to adapt them to buyer-supplier relationships [12,37-39].

At the internal chain level, some HR practices have been identified as key to inventory and material management performance $[40,41]$, in particular aligned managerial incentives [42]. At the external chain level, Scarbrough [13] highlighted the need for socialization

Table 1. Classification of organizational facilitators and inhibitors of supply relationship integration.

\begin{tabular}{|c|c|c|}
\hline & $\begin{array}{l}\text { Personal/Cultural } \\
\text { (Founded on social } \\
\text { interactions) }\end{array}$ & $\begin{array}{c}\text { Impersonal/bureaucratic } \\
\text { /technocratic } \\
\text { (Founded on instrumental } \\
\text { artifacts) }\end{array}$ \\
\hline $\begin{array}{l}\text { Direct/ } \\
\text { explicit }\end{array}$ & + Direct Supervision & + Standardization of work \\
\hline $\begin{array}{l}\text { Indirect/ } \\
\text { implicit }\end{array}$ & $\begin{array}{c}\text { + Shared values } \\
+ \text { Mutual adjustment } \\
\text {-Political considerations } \\
\text {-Frame differences }\end{array}$ & $\begin{array}{l}\text {-Goal differences } \\
\text {-Resource allocation }\end{array}$ \\
\hline
\end{tabular}

through teamworking, training and employee involvement in order to meet the supply chain requirements.

HR issues within intra and inter-firm networks have also received attention, notably as regards the creation of dynamic network capabilities $[43,44]$ and interorganizational knowledge transfers $[45,46]$.

The various contributions of this body of literature may be generalized to posit that HRPs influence the quality and effectiveness of supply relationships, either in inter- or intra-firm contexts. A set of "high performance work practices" such as heavy investments in training and selective hiring practices [47] may support buyer-supplier interaction. By extension, HRPs can influence supply relationships integration as previously defined. In the service operations context, Gittel [11] showed that HR practices could be designed to promote coordination within a single function, a single site or a single stage of the supply chain; Chuang and Liao [48] also highlight the role of HRPs in encouraging cooperative behaviors. HRPs support relational coordination defined as "coordination that occurs through frequent, highquality communication, supported by relationships of shared goals, shared knowledge, and mutual respect" (Gittel [11] p. 730). A feature of HR practices that promote relational coordination is that they are based on outcomes at collective rather than individual level [10].

HR practices may be insulated from the supply relationship $[13,14]$ and focused on achieving goals at single site level. Such HRPs are viewed as "specialized"; they have been proved to hinder the development of supply relationships, in inter- [14,49] and intra-firm contexts [15]. We propose that these specialized HRPs obstruct supply relationship integration by acting as antecedents of organizational inhibitors of integration. Conversely, HR practices that are adapted to the supply relationship, aligned on shared goals and which promote shared knowledge and mutual respect at relationship level foster the development of supply relationships $[14,15,49]$. Such HRPs are labeled "relational"; they promote supply relationship integration by acting as antecedents of organizational facilitators of integration.

We further propose that the set of specialized and relational HRPs differ in intra- and inter-organizational contexts. This assumption is based on a contextual or configurational approach of human resource practices [25] that has been applied to internal as well as external organizational contexts [8,50]. Figure 1 shows the conceptual model which underpins our research.

\section{Methods}

Case studies can be used for different types of research purposes, including theory building, which identify and describe key variables and their linkages, and theory 


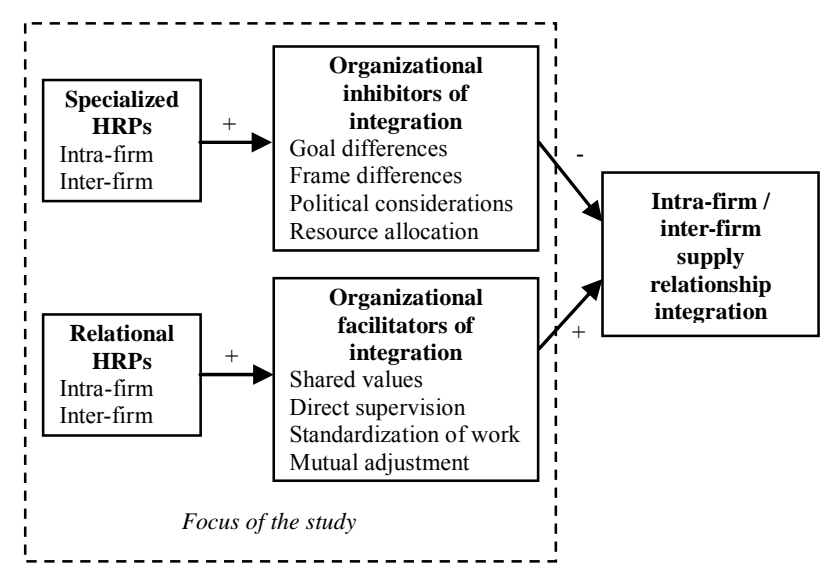

Figure 1. Conceptual model.

testing. Voss et al. [51] argue that research questions may evolve over time with a change of focus from theory building to theory testing. Our study reflects such an approach. It draws on the cross-case analysis [52] from two exploratory cases: Wheatco-Chemco [14] and Tyrenco [15]. Wheatco and Chemco were two separate partners physically situated next to each other on a site in the UK and bound through a reciprocally interdependent relationship. The Tyrenco case was based on an intra-firm supply relationship between the drug manufacturing and finishing divisions of a pharmaceutical organization, which were situated in France and the UK respectively.

Amundson [53] argues that the use of a different theoretical lens can "cause identical situations to be viewed differently, suggesting different course of actions for observers' (p. 347) and provide a different interpretation of the same situation. This form of theoretical triangulartion [54,55] helps avoid potential blind spots linked to the theoretical lens. This paper re-analyses the two qualitative dataset to test the relevance of organizational integration constructs $[4,6]$ in highlighting the role of seven HR practices in intra- and inter-firm integration.

In both cases, the unit of analysis was the relationship (at inter- and intra-firm level), rather than the single organizational unit (the site). A feature of the research design was 84 semi-structured interviews (48 in one and 36 in the other) with a wide cross-section of employees and managers from both sides of the two dyad. The aim was to collect rich data, which was "pluralist" in nature, hence providing competing versions of reality [56]. The seven HR practices observed included: staffing, job design, appraisals, rewards, training, socialization and communication.

Data coding includes different steps. The two qualitative datasets were first analyzed using deductive and inductive coding to highlight the HR issues associated with supply chain relationships and to identify specialized versus relational HRPs. This analysis has been presented in earlier papers $[14,15,49]$. For the purpose of this study, the dataset has been re-coded in an inductive manner to interpret the specialized and relational HRPs as antecedents of integration organizational drivers. Systematic matrix analysis will be provided in the next section.

\section{Results and Discussion}

\subsection{The Specialized and Relational Approaches to HRPs Take Similar and Specific Forms in the Intra and Inter-Firm Contexts}

Intra and inter-firm contexts present specific specialized and relational HRPs, but they also show many similarities (Table 2). This result suggests that the requirements of supply relationships are very close in intra and interorganizational contexts, thus designing similar roles for HRPs, but the particular answers and practices developed to meet those requirements may differ according to the context.

The many similarities between intra- and inter-firm confirm that integration in any context requires a broad holistic approach, which is supported by relational practices such as shared objectives and extended socialization and which is hindered by specialized practices such as a focus on internal work organization or appraisal criteria. Yet the literature also argues for a specific approach of integration process within the inter- and intra-firm contexts $[4,7]$.

The presence of specialized HRPs in the two contexts highlights the persistence of a fragmented, transactional approach within supply chains. The holistic and relational approach underpinning the integration literature encounters many barriers.

The limit of the relational approach in inter-firm buyer-supplier relationships reflects the complexity and uncertainty of competitive environments, which create conflicting demands on firms. On the one hand, there is a need for operational performance and flexibility, which are achieved through relational practices. On the other hand, strategic flexibility also calls for transactional practices. As Mahapatra et al. [57] (p.537) state, "firms operate in environments where the contextual contingencies do not present ideal conditions for practicing purely relational or transactional approach (...). Developing an effective exchange arrangement (...) is especially difficult due to the potential mismatch in resource capabilities, strategic priorities, and organizational legacy/culture of the counterparts."

The limit of the relational approach in intra-firm buyer-supplier relationships reflects the debate over the required level of centralization needed in MNCs or multi-site companies. The tension between decentralizetion and centralization echoes the cultural distance and inter-unit power struggles that arise in internal contexts and make intra-firm supply chains difficult to manage [15]. 
Table 2. Identification of specialized versus relational HRPs in the intra and inter-firm contexts.

\begin{tabular}{|c|c|c|c|}
\hline & & Specialized HRPs & Relational HRPs \\
\hline \multirow{2}{*}{ Staffing } & $\begin{array}{l}\text { Similar to } \\
\text { intra and } \\
\text { inter-firm } \\
\text { contexts }\end{array}$ & $\begin{array}{l}\text { People turnover } \\
\text { Focus on internal } \\
\text { selection criteria }\end{array}$ & $\begin{array}{c}\text { Employee inter-site } \\
\text { transfers } \\
\text { Relational } \\
\text { competency as } \\
\text { selection criteria }\end{array}$ \\
\hline & $\begin{array}{l}\text { Inter-firm } \\
\text { specific }\end{array}$ & $\begin{array}{l}\text { Caliber of employees } \\
\text { signals the priority } \\
\text { assigned to the } \\
\text { relationship }\end{array}$ & \\
\hline \multirow{3}{*}{ Job design } & Similar & $\begin{array}{c}\text { Job design focused } \\
\text { on internal work } \\
\text { organization }\end{array}$ & $\begin{array}{c}\text { Broad job designs } \\
\text { Contact points, roles } \\
\text { and responsibilities } \\
\text { clarified }\end{array}$ \\
\hline & $\begin{array}{l}\text { Intra-firm } \\
\text { specific }\end{array}$ & $\begin{array}{c}\text { Decision making } \\
\text { power; neutrality and } \\
\text { impartiality }\end{array}$ & $\begin{array}{l}\text { End-to-end jobs } \\
\text { Design of job with } \\
\text { end-to-end authority }\end{array}$ \\
\hline & $\begin{array}{l}\text { Inter-firm } \\
\text { specific }\end{array}$ & $\begin{array}{c}\text { Lack of information } \\
\text { on partner's job } \\
\text { design }\end{array}$ & \\
\hline \multirow{2}{*}{ Appraisals } & Similar & $\begin{array}{l}\text { Focus on internal } \\
\text { appraisal criteria } \\
\text { Other priorities }\end{array}$ & $\begin{array}{c}\text { Shared objectives } \\
\text { include a relational } \\
\text { element }\end{array}$ \\
\hline & $\begin{array}{l}\text { Inter-firm } \\
\text { specific }\end{array}$ & & Informal appraisals \\
\hline \multirow[t]{2}{*}{ Rewards } & Similar & $\begin{array}{c}\text { Bonus aligned on } \\
\text { conflicting objectives } \\
\text { Concern for intra-site } \\
\text { consistency }\end{array}$ & \\
\hline & $\begin{array}{l}\text { Intra-firm } \\
\text { specific }\end{array}$ & & $\begin{array}{c}\text { Based on } \\
\text { end-to-end goals }\end{array}$ \\
\hline \multirow{3}{*}{$\begin{array}{l}\text { Training/ } \\
\text { socialization }\end{array}$} & Similar & $\begin{array}{l}\text { Lack of priority for } \\
\text { human elements }\end{array}$ & $\begin{array}{c}\text { Extended } \\
\text { socialization rather } \\
\text { than formal training }\end{array}$ \\
\hline & $\begin{array}{l}\text { Intra-firm } \\
\text { specific }\end{array}$ & $\begin{array}{l}\text { Seminars highlight } \\
\text { technical vs } \\
\text { social/human/ } \\
\text { relational } \\
\text { Language barriers }\end{array}$ & \\
\hline & $\begin{array}{l}\text { Inter-firm } \\
\text { specific }\end{array}$ & & $\begin{array}{c}\text { Formal program } \\
\text { of visits } \\
\text { Induction programs } \\
\text { for new recruits }\end{array}$ \\
\hline \multirow{3}{*}{$\begin{array}{l}\text { Communi- } \\
\text { cation }\end{array}$} & Similar & & $\begin{array}{l}\text { Clear joint message } \\
\text { from top management }\end{array}$ \\
\hline & $\begin{array}{l}\text { Intra-firm } \\
\text { specific }\end{array}$ & $\begin{array}{l}\text { Lack of joint top } \\
\text { management goals; } \\
\text { political agendas }\end{array}$ & \\
\hline & $\begin{array}{l}\text { Inter-firm } \\
\text { specific }\end{array}$ & & $\begin{array}{c}\text { Joint steering } \\
\text { committee charter }\end{array}$ \\
\hline
\end{tabular}

\subsection{The Specialized and Relational Approaches to HR Practices as Inhibitors and Facilitators of Integration}

Table 3 shows that there were a number of similarities across both cases regarding the HR practices that inhib- ited relationship integration. Thus staffing decisions based on internal site priorities resulted in high people turnover perceived at relationship level. This disrupted the existing routines and inter-personal communication and created a lack of trust. Job design which was focused on the internal work organization and did not allow much direct interface and face to face communication caused a lack of understanding of the partner's operations and work organization. Appraisals and rewards driven by local goals and focused on internal site performance caused conflict and blame culture. Training and socialization that did not foster face to face interaction at relationship level further reinforced the lack of information sharing and the lack of understanding between the partners. Finally, lack of communication about the benefits of the relationship failed to promote collaboration.

Beside their local goal orientation, HR practices were influenced by political considerations: the resources needed to integrate the relationship were competing with internal resource allocation. This was particularly true within the intra-firm context, where political barriers and survival issues were prevailing.

Whilst the specialized approach characterized the first period of both fieldworks, following various quality and customer service issues a more relational approach was implemented that sought to improve the relationship performance through better integration (Table 4).

Thus the HR practices were modified or new processes were introduced to better enable relationship integration. Thus staffing decisions resulting in appointing an employee who was familiar with the partner's organization (a transfer in the intra-firm case) created an improved environment for problem solving. Job design now resulted in roles that promoted cooperation, and the design of appraisals and rewards was based on shared objectives and goals. Training and socialization processes that provided opportunities for formal as well as informal interactions were conducive to joint sense making and knowledge sharing. Finally, communication clarified the strategic importance of the supply relationship.

\subsection{Comparing the Role of HR Practices in Inter- and Intra-Firm Supply Relationships}

This research confirms the well documented role of goal differences as inhibitor of integration within the interand intra-firm relationship [4]. It also highlights the prevailing role of political processes within the intra-firm context: conflicts over territorial and survival issues. At inter-firm level, political considerations were also expressed: as partners engage in supply relationships, these compete with other priorities for scarce resources. The study stresses the prevalence of frame differences within intra- as well as inter-firm relationship. 
Table 3. Specialized approach to HR practices as antecedent of integration organizational inhibitors.

\begin{tabular}{|c|c|c|c|c|c|c|c|}
\hline \multirow{3}{*}{ HR practice } & \multirow{3}{*}{ Specialized practices } & \multicolumn{4}{|c|}{ Inhibitors of integration } & \multirow{3}{*}{ Inter } & \multirow{3}{*}{ Intra } \\
\hline & & \multicolumn{2}{|c|}{ Specialization } & \multicolumn{2}{|c|}{ Politics } & & \\
\hline & & GD & FD & $\mathrm{PO}$ & $\mathrm{RE}$ & & \\
\hline \multirow{3}{*}{ Staffing } & $\begin{array}{l}\text { Lack of experience of employees appointed to work on the } \\
\text { relationship interpreted as a lack of priority }\end{array}$ & & & $\mathrm{X}$ & $\mathrm{X}$ & $\mathrm{X}$ & \\
\hline & People turnover disrupts inter-personal relationships and routines & & $\mathrm{X}$ & & & $\mathrm{X}$ & $\mathrm{X}$ \\
\hline & Internal criteria as main driver & $\mathrm{X}$ & & & & $\mathrm{X}$ & $\mathrm{X}$ \\
\hline \multirow{3}{*}{ Job design } & Lack of information on partner's job design & & $\mathrm{X}$ & & & $\mathrm{X}$ & \\
\hline & Decision making power; neutrality and impartiality & & & $\mathrm{X}$ & & & $\mathrm{X}$ \\
\hline & Handled separately by the two partners & $\mathrm{X}$ & & & & $\mathrm{X}$ & $\mathrm{X}$ \\
\hline \multirow{2}{*}{ Appraisals } & Internal criteria as main driver & $\mathrm{X}$ & & & & $\mathrm{X}$ & $\mathrm{X}$ \\
\hline & Other priorities & & & $\mathrm{X}$ & & $\mathrm{X}$ & $\mathrm{X}$ \\
\hline \multirow{2}{*}{ Rewards } & Bonus aligned on conflicting objectives & $\mathrm{X}$ & & & & $\mathrm{X}$ & $\mathrm{X}$ \\
\hline & Concern for intra-site consistency (unions) & & & $\mathrm{X}$ & & $\mathrm{X}$ & $\mathrm{X}$ \\
\hline \multirow{3}{*}{$\begin{array}{l}\text { Training/ } \\
\text { socialisation }\end{array}$} & Seminars highlight technical vs. social/human/relational & & $\mathrm{X}$ & & $\mathrm{X}$ & & $\mathrm{X}$ \\
\hline & Language as barrier & & $\mathrm{X}$ & $X$ & & & $X$ \\
\hline & $\begin{array}{l}\text { Cancellation of socialization events viewed as "jolly". } \\
\text { Lack of priority for human element }\end{array}$ & & & $\mathrm{X} ?$ & $\mathrm{X}$ & $\mathrm{X}$ & $\mathrm{X}$ \\
\hline Communication & Lack of joint Top management goals; political agendas & $\mathrm{X}$ & & $\mathrm{X}$ & & & $\mathrm{X}$ \\
\hline
\end{tabular}

GD: goal differences; FD: frame differences; PO: political considerations; RE: resource allocation.

Table 4. Relational approach to HR practices as antecedent of integration organizational facilitators.

\begin{tabular}{|c|c|c|c|c|c|c|c|}
\hline \multirow{2}{*}{ HR practice } & \multirow{2}{*}{ Relational practices } & \multicolumn{4}{|c|}{ Facilitators of integration } & \multirow{2}{*}{ Inter } & \multirow{2}{*}{ Intra } \\
\hline & & SV & DS & $\mathrm{St}$ & MA & & \\
\hline \multirow{2}{*}{ Staffing } & Transfers from one site to another as bridge-builders & $\mathrm{X}$ & & & $\mathrm{X}$ & $\mathrm{X}$ & $\mathrm{X}$ \\
\hline & Specific relational competency required to work on the relationship & $\mathrm{X}$ & & & $\mathrm{X}$ & $\mathrm{X}$ & $\mathrm{X}$ \\
\hline \multirow{4}{*}{ Job design } & Broader jobs & $\mathrm{X}$ & & & $\mathrm{X}$ & $\mathrm{X}$ & $\mathrm{X}$ \\
\hline & End-to-end jobs & $\mathrm{X}$ & & & $\mathrm{X}$ & & $\mathrm{X}$ \\
\hline & Design of job with end-to-end authority & & $\mathrm{X}$ & & & & $\mathrm{X}$ \\
\hline & Clarify contact points and roles and responsibility. & & & $\mathrm{X}$ & & $\mathrm{X}$ & $\mathrm{X}$ \\
\hline Appraisals & Shared objectives includes a relational element & & & & & $\mathrm{X}$ & $\mathrm{X}$ \\
\hline Rewards & Based on end-to-end goals & $\mathrm{X}$ & & & $\mathrm{X}$ & & $\mathrm{X}$ \\
\hline \multirow{3}{*}{$\begin{array}{c}\text { Training/ } \\
\text { socialisation }\end{array}$} & Extended socialization preferred to formal training & $\mathrm{X}$ & & & $\mathrm{X}$ & $\mathrm{X}$ & $\mathrm{X}$ \\
\hline & Formal program of visits & $\mathrm{X}$ & & $\mathrm{X}$ & & $\mathrm{X}$ & \\
\hline & Induction programs for new recruits & $\mathrm{X}$ & & $\mathrm{X}$ & $\mathrm{X}$ & $\mathrm{X}$ & \\
\hline \multirow{2}{*}{ Communication } & Joint steering committee charter & $\mathrm{X}$ & & $\mathrm{X}$ & & $\mathrm{X}$ & \\
\hline & Need for clear joint message from top management & $\mathrm{X}$ & $\mathrm{X}$ & & & $\mathrm{X}$ & $\mathrm{X}$ \\
\hline
\end{tabular}

SV: shared values; DS: direct supervision; St: standardization; MA: mutual adjustment. 
Both at inter and intra-firm level, a focus on the "technical" side of the relationship induced a lack of priority for the "soft" or human" aspects, with socialization viewed as time wasting event [9].

A strength of the intra-firm context was the ability to use the hierarchy to impose integration through a relational approach, for example by designing HR practices (jobs, rewards and supervision mechanisms) that spanned the end-to-end internal supply chain. Conversely, the inter-firm context drew on informal practices that supported mutual adjustment [2] necessary to operate the supply relationship.

Two elements were not specifically highlighted in the literature and therefore merit further investigation: the role of standardization of work as integration mechanism in the inter-firm and of mutual adjustment at intra-firm level. Indeed, at inter-firm level, the context of interdependence required formal plans to ensure that HR processes took place. To some extent, standardization acted as a proxy for hierarchical integration. The importance of mutual adjustment and shared values at intra-firm level highlights the need for relational processes within an internal interdependent operational context [58].

We may conclude that in the intra-firm context, the use of hierarchy as integration mechanisms fosters the emergence of direct/explicit drivers of integration, which then appear as "natural" drivers. Implicit drivers conversely require higher levels of implementation effort, in particular implicit social interaction drivers such as mutual adjustment that has been found to require specific attention. As regards the inter-firm context, the urge to get to know each other and to build a common project for integration favors a fast implementation of implicit drivers, which then appear as the most "natural" drivers of integration. Explicit drivers require most of the integration implementation effort, notably instrumental direct drivers such as standardization of work. Tables 5 and 6 summarize these propositions.

Managerial implications can be drawn from this analysis. In intra-firm integration contexts, managers are naturally more focused on direct drivers of integration supported by hierarchical mechanisms. Our findings

Table 5. Characterization of organizational drivers of integration within the intra-firm context.

\begin{tabular}{ccc}
\hline & $\begin{array}{c}\text { Personal/Cultural } \\
\text { (Founded on social } \\
\text { interactions) }\end{array}$ & $\begin{array}{c}\text { Impersonal/bureaucratic/ } \\
\text { technocratic } \\
\text { (Founded on instrumental } \\
\text { artefacts) }\end{array}$ \\
\hline $\begin{array}{c}\text { Direct/ } \\
\text { explicit }\end{array}$ & $\begin{array}{c}\text { Natural drivers } \\
\text { (easily implemented) }\end{array}$ & $\begin{array}{c}\text { Natural drivers } \\
\text { (easily implemented) }\end{array}$ \\
Indirect/ & $\begin{array}{c}\text { Critical drivers (very } \\
\text { implicit } \\
\text { implementation effort) }\end{array}$ & $\begin{array}{c}\text { Built drivers (requiring } \\
\text { implementation effort) }\end{array}$ \\
\hline
\end{tabular}

Table 6. Characterization of organizational drivers of integration within the inter-firm context.

\begin{tabular}{|c|c|c|}
\hline & $\begin{array}{l}\text { Personal/Cultural } \\
\text { (Founded on social } \\
\text { interactions) }\end{array}$ & $\begin{array}{c}\text { Impersonal/bureaucratic/ } \\
\text { technocratic } \\
\text { (Founded on instrumental } \\
\text { artefacts) }\end{array}$ \\
\hline $\begin{array}{l}\text { Direct/ } \\
\text { explicit }\end{array}$ & $\begin{array}{l}\text { Built drivers (requiring } \\
\text { implementation effort) }\end{array}$ & $\begin{array}{c}\text { Critical drivers (very } \\
\text { important yet requiring } \\
\text { high implementation effort) }\end{array}$ \\
\hline $\begin{array}{l}\text { Indirect/ } \\
\text { implicit }\end{array}$ & $\begin{array}{c}\text { Natural drivers } \\
\text { (easily implemented) }\end{array}$ & $\begin{array}{c}\text { Natural drivers } \\
\text { (easily implemented) }\end{array}$ \\
\hline
\end{tabular}

suggest that they should also be aware of the importance of implicit drivers of integration. In particular, they should pay special attention to designing HRPs in such a way that they favor mutual adjustment. Conversely, social bonding, along with indirect organizational drivers, is the natural practice of managers looking for inter-firm integration. Our findings suggest that priority should also be given to the formal construction of integration through standardization of work. Table 4 provides examples of HRPs that can be implemented for those matters.

\section{Conclusion}

This paper reanalyzes the cases in two earlier papers $[14,15]$ by linking the specialized and relational approaches to HR practices to integration constructs from organizational literature. The study addresses the call for including human aspects into integration constructs [4] and it contributes to operations management by drawing on "alien" theoretical perspectives [53] and by further bridging the OM and HRM literature.

This study was limited in that it drew on inductive data collected from two dyadic relationships and therefore could not be used to generalize. Large sample data collection would be needed to test the proposed role of HR practices in inhibiting or facilitating integration. In particular, more research is required to investigate the role of standardization in integrating inter-firm contexts and the role of mutual adjustment within intra-firm supply relationships.

\section{REFERENCES}

[1] M. Fröhlich and R. Westbrook, "Arcs of Integration: An International Study of Supply Chain Strategies," Journal of Operations Management, Vol. 24, 2001, pp. 563-582.

[2] J. Thompson, "Organizations in Action," McGraw-Hill, New York, 1967.

[3] L. Hallen, J. Johanson and N. Seyed-Mohamed, "Interfirm Adaptation in Business Relationships," Journal of Marketing, Vol. 55, No. 2, 1991, pp. 29-37. http://dx.doi.org/10.2307/1252235

[4] H. Barki and A. Pinsonneault, "A Model of Organiza- 
tional Integration, Implementation Effort, and Performance," Organizational Science, Vol. 16, No. 2, 2005, pp. 165-179. http://dx.doi.org/10.1287/orsc.1050.0118

[5] A. Das, R. Narasimhan and T. Srinivas, "Supplier Integration-Finding an Optimal Configuration," Journal of Operations Management, Vol. 24, No. 5, 2006, pp. 563582. http://dx.doi.org/10.1016/j.jom.2005.09.003

[6] M. Hitt, R. Hoskisson and R. Nixon, "A Mid-Range Theory of Interfunctional Integration, Its Antecedents and Outcomes," Journal of Engineering and Technology Management, Vol. 10, No. 1-2, 1993, pp. 161-185. http://dx.doi.org/10.1016/0923-4748(93)90062-N

[7] M. Pagell, "Understanding the Factors That Enable and Inhibit the Integration of Operations, Purchasing and Logistics," Journal of Operations Management, Vol. 22, No. 5, 2004, pp. 459-487.

http://dx.doi.org/10.1016/j.jom.2004.05.008

[8] D. Lepak and S. Snell, "The Human Resource Architecture: Toward a Theory of Human Capital Allocation and Development," Academy of Management Review, Vol. 24, 1999, pp. 31-48.

[9] P. D. Cousins and B. Menguc, "The implications of Socialization and Integration in Supply Chain Management," Journal of Operations Management, Vol. 24, No. 5, 2006, pp. 604-620. http://dx.doi.org/10.1016/j.jom.2005.09.001

[10] J. Gittell, "Organizing Work to Support Relational CoOrdination," International Journal of Human Resource Management, Vol. 11, No. 3, 2000, pp. 517-539. http://dx.doi.org/10.1080/095851900339747

[11] J. Gittell, D. Weinberg, A. Bennett and J. Miller, "Is the Doctor in? A Relational Approach to Job Design and the Coordination of Work," Human Resource Management, Vol. 47, No. 4, 2008, pp. 729-755. http://dx.doi.org/10.1002/hrm.20242

[12] L. Hunter, P. Beaumont and D. Sinclair, "A 'Partnership' Route to Human Resource Management?” Journal of Management Studies, Vol. 33, No. 2, 1996, pp. 235-57. http://dx.doi.org/10.1111/j.1467-6486.1996.tb00159.x

[13] H. Scarbrough, "The HR Implications of Supply Chain Relationships," Human Resource Management Journal, Vol. 10, No. 1, 2000, pp. 5-17. http://dx.doi.org/10.1111/j.1748-8583.2000.tb00010.x

[14] M. Koulikoff-Souviron and A. Harrison, "The Pervasive Human Resource Picture in Interdependent Supply Relationships," International Journal of Operations and Production Management, Vol. 27, No. 1, 2007, pp. 8-27. http://dx.doi.org/10.1108/01443570710714510

[15] M. Koulikoff-Souviron and A. Harrison, "Evolving HR practices in a Strategic Intra-Firm Supply chain," Human Resource Management, Vol. 49, No. 5, 2010, pp. 1-26. http://dx.doi.org/10.1002/hrm.20388

[16] B. B. Flynn, B. Huo and X. Zhao, "The Impact of Supply Chain Integration on Performance: A Contingency and Configuration approach," Journal of Operations Management, Vol. 28, No. 1, 2010, pp. 58-71. http://dx.doi.org/10.1016/j.jom.2009.06.001

[17] N. Fabbe-Costes and M. Jahre, "Supply Chain Integration and Performance:A Review of the Evidence," Interna- tional Journal of Logistics Management, Vol. 19, No. 2, 2008, pp. 130-154.

http://dx.doi.org/10.1108/09574090810895933

[18] H. Forslund and P. Jonsson, "Obstacles to Supply Chain Integration of the Performance Management Process in Buyer-Supplier Dyads: The Buyers' Perspective," International Journal of Operations and Production Management, Vol. 19, No. 1, 2009, pp. 185-200.

http://dx.doi.org/10.1016/j.jom.2007.08.002

[19] X. Zhao, B. Huo, B. B. Flynn and J. Hoi Yan Yeung, "The Impact of Power and Relationship Commitment on the Integration between Manufacturers and Customer in a Supply Chain," Journal of Operations Management, Vol. 26, 2008, pp. 368-388.

[20] S. Glouberman and H. Mintzberg, "Managing the Care of Health and the Cure of Disease-Part II Integration," Health Care Management Review, Vol. 26, No.1, 2001, pp. 70-84. http://dx.doi.org/10.1097/00004010-200101000-00007

[21] A. W. K. Harzing, "Managing the Multinationals: An International Study of Control Mechanisms," Edward Elgar, Cheltenham, 1999.

[22] N. J. Kinnie and R. Staughton, "Implementing Manufacturing Strategy: The Human Resource Management Contribution," International Journal of Operations and Production Management, Vol. 11, No. 9, 1991, pp. 24-40. http://dx.doi.org/10.1108/EUM0000000001283

[23] D. Leonard-Barton, "The Factory as a Learning Laboratory," Sloan Management Review, Vol. 34, No.1, 1992, pp. 23-38.

[24] J. Arthur, "Effects of Human Resource Systems on Manufacturing Performance and Turnover," Academy of Management Journal, Vol. 37, No. 3, 1994, pp. 670-687. http://dx.doi.org/10.2307/256705

[25] J. P. MacDuffie, "Human Resource Bundles and Manufacturing Performance: Organizational Logic and Flexible Production Systems in the World Auto Industry," Industrial and Labor Relations Review, Vol. 48, No. 2, 1995, pp. 197-221. http://dx.doi.org/10.2307/2524483

[26] R. Banker, J. Field, R. Schroeder, G. Roger and K. Sintia, "Impact of Work Teams on Manufacturing Performance: a Longitudinal Field Study," Academy of Management Journal, Vol. 39, No. 4, 1996, pp. 867-890. http://dx.doi.org/10.2307/256715

[27] M. Youndt, S. Snell, J. Dean and D. Lepak, "Human Resource Management, Manufacturing Strategy and Firm Performance," Academy of Management Journal, Vol. 39, No. 4, 1996, pp. 836-866. http://dx.doi.org/10.2307/256714

[28] C. Ichniowski, K. Show and G. Prennushi, "The Effects of Human Resource Management Practices on Productivity: A Study of Steel Finishing Lines," The American Economic Review, Vol. 87, No. 3, 1997, pp. 291-313.

[29] J. Storey and A. Harrison, "Coping with World Class Manufacturing," Work, Employment and Society, Vol. 13, No. 4, 1999, pp. 643-664.

[30] P. Lorange, "Human Resource Management in Multinational Cooperative Ventures", Human Resource Management, Vol. 25, No.1, 1986, pp.133-148. 
http://dx.doi.org/10.1002/hrm.3930250110

[31] R. N. Ashkenas, "A New Paradigm for Customer and Supplier Relationships," Human Resource Management, Vol. 29, No. 4, 1990, pp. 385-396. http://dx.doi.org/10.1002/hrm.3930290405

[32] T. D. Jick, "Customer-Supplier Partnerships: Human Resources as Bridge Builders," Human Resource Management, Vol. 29, No. 4, 1990, pp. 435-454. http://dx.doi.org/10.1002/hrm.3930290408

[33] D. Lake, "Key Interfaces: New Opportunities for Human Resources," Human Resource Management, Vol. 29, No. 4, 1990, pp. 397-410. http://dx.doi.org/10.1002/hrm.3930290406

[34] R. M. Kanter, "Collaborative Advantage: the Art of Alliances," Harvard Business Review, Vol. 74, No. 4, 1994, pp. 96-108.

[35] N. J. Kinnie, J. Swart and J. Purcell, "Influences on the Choice of HR System: The Network Organization Perspective," International Journal of Human Resource Management, Vol. 16, No. 6, 2005, pp. 1004-1028. http://dx.doi.org/10.1080/09585190500120780

[36] R. Schuler and S. Jackson, “A Quarter Century Review of Human Resource Management in the US: The Growth in Importance of the International Perspective," Management Revue, Vol. 16, No. 1, 2005, pp. 11-35.

[37] P. B. Beaumont, L. C. Hunter and D. Sinclair, "CustomerSupplier Relations and the Diffusion of Employee Relations Changes," Employee Relations, Vol. 18, No. 1, 1996, pp. 9-19. http://dx.doi.org/10.1108/01425459610110209

[38] J. Rubery, M. Carroll, F. Cooke, I. Grugulis and J. Earnshaw, "Human Resource Management and the Permeable Organization: The Case of the Multiclient Call Center," Journal of Management Studies, Vol. 41, No. 7, 2004, pp. 1199-1222.

http://dx.doi.org/10.1111/j.1467-6486.2004.00472.x

[39] J. Swart and N. Kinnie, "Knowledge-Intensive Firms: The Influence of the Client on HR Systems," Human Resource Management Journal, Vol. 13, No. 3, 2003, pp. 37-55. http://dx.doi.org/10.1111/j.1748-8583.2003.tb00097.x

[40] H. Lee and C. Billington, "Managing Supply Chain Inventory: Pitfalls and Opportunities," Sloan Management Review, Vol. 33, No. 3, 1992, pp. 65-73.

[41] H. Lee and C. Billington, "Materials Management in Decentralized Supply Chains," Operations Research, Vol. 41, No. 5, 1993, pp. 835-847. http://dx.doi.org/10.1287/opre.41.5.835

[42] H. L. Lee and S. Whang, "Decentralized Multiechelon Supply Chains: Incentives and Information," Management Science, Vol. 45, No. 5, 1999, pp. 633-640. http://dx.doi.org/10.1287/mnsc.45.5.633

[43] C. Snow, R. Miles and H. Coleman, "Managing 21st Century Network Organizations," Organizational Dynamics, Vol. 20, No. 3, 1992, pp. 5-20. http://dx.doi.org/10.1016/0090-2616(92)90021-E

[44] C. Buhman, K. Sunder and J. Singhal, "Interdisciplinary and Interorganizational Research: Establishing the Science of Enterprise Networks," Production and Operations Management, Vol. 14, No. 4, 2005, pp. 493-513. http://dx.doi.org/10.1111/j.1937-5956.2005.tb00236.x
[45] J. Dyer and K. Nobeoka, "Creating and Managing a High Performance Knowledge Sharing Network: The Toyota Case," Strategic Management Journal, Vol. 21, No. 3, 2000, pp. 345-367. http://dx.doi.org/10.1002/(SICI)1097-0266(200003)21:3< 345::AID-SMJ96>3.0.CO;2-N

[46] J. Dyer and N. Hatch, "Relation-Specific Capabilities and Barriers to Knowledge Transfers: Creating Advantage through Network Relationships," Strategic Management Journal, Vol. 27, No. 8, 2006, pp. 701-719. http://dx.doi.org/10.1002/smj.543

[47] J. Combs, Y. Liu, A. Hall and D. Ketchen, "How much do High-Performance Work Practices Matter? A Meta-Analysis of Their Effects on Organizational Performance," Personnel Psychology, Vol. 59, No. 3, 2006, pp. 501-528. http://dx.doi.org/10.1111/j.1744-6570.2006.00045.x

[48] C. H. Chuang and H. Liao, "Strategic Human Resource Management in Service Context: Taking Care of Business by Taking Care of Employees and Customers," Personnel Psychology, Vol. 63, No. 1, 2010, pp. 153-196. http://dx.doi.org/10.1111/j.1744-6570.2009.01165.x

[49] M. Koulikoff-Souviron and A. Harrison, "Interdependent Supply Relationships as Institutions: The Role of HR Practices," International Journal of Operations and Production Management, Vol. 28, No. 5, 2008, pp. 412-432. http://dx.doi.org/10.1108/01443570810867187

[50] D. P. Lepak and S. Snell, "Examining the Human Resource Architecture: The Relationships among Human Capital, Employment, and Human Resource Configurations," Journal of Management, Vol. 28, No. 4, 2002, pp. 517-543.

[51] C. Voss, N. Tsikritiktsis and M. Frohlich, "Case Research in Operations Management," International Journal of Operations and Production Management, Vol. 22, No. 2, 2002, pp. 195-219.

http://dx.doi.org/10.1108/01443570210414329

[52] C. C. Ragin, "The Comparative Method," University of California Press, Berkeley, 1987.

[53] S. D. Amundson, "Relationships between Theory-Driven Empirical Research in Operations Management and Other Disciplines," Journal of Operations Management, Vol. 16, No. 4, 1998, pp. 341-359. http://dx.doi.org/10.1016/S0272-6963(98)00018-7

[54] T. D. Jick, "Mixing Qualitative and Quantitative Methods: Triangulation in Action," Administrative Science Quarterly, Vol. 24, No. 4, 1979, pp. 602-611. http://dx.doi.org/10.2307/2392366

[55] R. Yin, "Case Study Research," 3rd Edition, Sage, Thousand Oaks, 2003.

[56] A. M. Pettigrew, "Longitudinal Field Research on Change: Theory and Practice," Organization Science, Vol. 1, No. 3, 1990, pp. 267-292. http://dx.doi.org/10.1287/orsc.1.3.267

[57] S. K. Mahapatraa, R. Narasimhanb and P. Barbieric, "Strategic Interdependence, Governance Effectiveness and Supplier Performance: A Dyadic Case Study Investigation and Theory Development," Journal of Operations Management, Vol. 28, No. 6, 2010, pp. 537-552. http://dx.doi.org/10.1016/j.jom.2010.04.001

[58] S. Ghoshal and P. Moran, "Bad for Practice: A Critique of the Transaction Cost Theory," Academy of Management Review, Vol. 21, No. 1, 1996, pp. 13-47. 